\title{
BookTube Młodzi dorośli o książkach i literaturze
}

\author{
BookTube \\ Young Adults about Books and Literature
}

Summary: The article is an introduction to the issue of BookTube, that is online movie channels related to books. The article presents an outline of the history of the creation of this type of vlogs, their evolution and the most important trends in its development. On the basis of selected examples, the main differences between the traditional review and the booktubers' ratings have been also examined, with particular emphasis on the influence of the environment on the formation of opinions and the selection of promoted works. The article also presents proposals for using BookTube in literary and cultural education as a tool that promotes the idea of deriving pleasure from reading.

Key words: BookTube, young adult literature, motivation for reading

\section{Jak nie czytają, jak czytają}

W mediach społecznościowych odnaleźć można wiele akcji mających na celu szeroko pojętą promocję czytelnictwa. Towarzyszące im hasła mogą budzić różne uczucia — niektóre mają być zabawne, inne mogą mile połechtać ego uczestników, we wszystkich można jednak dostrzec wyraźną tendencję do odżegnywania się od niepokojących statystyk dotyczących stanu czytelnictwa w Polsce. Dla przykładu wymienić można dwie najpopularniejsze inicjatywy, czyli Nie czytasz? Nie idę z Toba do tóżka i Nie jestem statystycznym Polakiem, lubię czytać książki. Pierwsza z nich została uznana za najlepszą kampanię spo- 
łeczną w 2011 roku, druga zrodziła się jako fanpage czytelniczy; obie natomiast, co najważniejsze, nadal rozwijają się całkiem prężnie, wprowadzając swoistą modę na czytanie. To już nie tylko spoty reklamowe z udziałem ludzi kultury czy plakaty, ale cały nowy przemysł z tematycznymi gadżetami i linią ubrań. Miłośnicy książek mogą więc bez trudu manifestować swoje poglądy z pomocą koszulek czy toreb z zabawnymi napisami.

$\mathrm{Na}$ tle wspomnianych projektów zdecydowanie wyróżniła się akcja Jak nie czytam, jak czytam, zorganizowana po raz pierwszy w 2016 roku przez redakcję czasopisma „Biblioteka w Szkole”. Skierowana była do młodzieży, a więc grupy niebranej pod uwagę w oficjalnych badaniach stanu czytelnictwa (przeprowadza się je przede wszystkim wśród osób powyżej 15. roku życia). Organizatorzy deklarowali, że młodych czytelników nie brakuje, a prawdziwym wyzwaniem jest nie tyle zwerbowanie nowych, co podtrzymanie przekonania o wartości lektury wśród tych już czytających ${ }^{1}$.

Założenia te wydają się jak najbardziej słuszne, zwłaszcza w kontekście tendencji do porzucania książek w wieku nastoletnim oraz związanej z nią potrzeby stymulowania czytania dla satysfakcji ${ }^{2}$. Badania pokazują, że najlepszym sposobem na promowanie idei lektury dla przyjemności jest wykorzystanie mediów, ponieważ to one stanowią dla młodzieży główne źródło wiedzy o książce, ale i o świecie, przez co wpływają na kształtowanie światopoglądu. Stąd też sugestia, by w procesie edukacji literacko-kulturowej śmiało wykorzystywać nowe technologie i sięgać po formy interaktywne, także w ramach motywacji do lektury ${ }^{3}$.

Gdzie jednak szukać treści, które mogłyby realnie zainteresować młodych odbiorców? Środowisko blogerów książkowych stanowi jedną z najlepiej rozwiniętych i najprężniej działających społeczności internetowych, podobnie rzecz ma się w przypadku vlogów (czyli videoblogów). Co więcej, środowisko blogerów tworzą przede wszystkim ludzie młodzi — przeważają wśród nich licealiści i studenci, a przedmiotem ich namysłu są przede wszystkim książki typu young adult i new adult, literatury popularnej dla młodzieży. Statystyki dowodzą również, że nie brakuje widowni, jako że materiały zamieszczane przez najpopularniejszych vlogerów śledzi nawet kilkadziesiąt tysięcy widzów, natomiast liczba kanałów poświęconych książkom stale wzrasta ${ }^{4}$. Być może to właśnie ten kanał komunikacji okaże się więc dobrym sposobem na zatrzymanie książki w życiu nastoletnich uczestników współczesnej kultury.

${ }^{1}$ Zob. J. Hys: Jak nie czytam, jak czytam. Bijemy rekord czytania w jednym momencie!. „Biblioteka w Szkole" 2017, nr 3, s. 3-5.

${ }^{2}$ Zob. Z. Zasacka: Czytelnictwo dzieci i młodzieży. Warszawa 2014, s. 164.

${ }^{3}$ Zob. ibidem, s. 165.

${ }^{4}$ Zob. R. Hetman: O tym, dlaczego jestem stary i co ogladam na BookTubie. https://czytam recenzuje.pl/ 1034/o-tym-dlaczego-jestem-stary-i-co-ogladam-na-booktubie [data dostępu: 10.01.2018]. 


\section{Internetowe życie czytelników}

BookTube, bo taką nazwą określa się vlogi poświęcone książkom i powiązaną z nimi społeczność, stanowi nieformalną, choć wyraźnie wyodrębnioną część serwisu YouTube. To przestrzeń przeznaczona dla osób kochających książki, ale też zainteresowanych dyskusją na ich temat, dzieleniem się wrażeniami i rekomendowaniem sobie kolejnych tytułów. Jego narodziny w polskojęzycznej wersji datuje się na lata 2012 — 2013, jednak pierwsze tego typu filmy zaczęły pojawiać się na YouTubie niewiele wcześniej — za prekursorki BookTube’a uznawane są siostry, Jessica i Stacy, które we wrześniu 2009 roku uruchomiły kanał o nazwie Beautyisntskindeep (mimo że wcześniej brały udział w tworzeniu YAFictionFreaks, gdzie pojawiały się podobne treści) ${ }^{5}$.

Polskojęzyczna wersja BookTube’a również nie jest wymysłem ostatnich lat, a wręcz przeciwnie - rozwijała się niemal równocześnie z tą anglojęzyczną. Jeden z pierwszych tego typu kanałów pojawił się jeszcze w 2008 roku, a jego autorką była uczennica (występowała wówczas na YouTubie jako Martha Oakiss, obecnie publikuje jako Wybredna Maruda). Autorka stworzyła BookTube'a, ponieważ chciała nawiązać kontakt z zainteresowanymi książką osobami, których nie potrafiła odnaleźć w codziennym życiu ${ }^{6}$. Taki powód przyłączenia się do społeczności booktuberów powtarza się zresztą często wśród młodych twórców, co każe zwrócić uwagę na funkcje wspólnototwórcze BookTube’a, skądinąd również niezwykle ważne dla młodzieży ${ }^{7}$. Realizowane są one poprzez umożliwienie dialogu między czytelnikami - toczącego się nie tylko w formie komentarzy pod filmami, ale także w zmieniających się tematyce i estetyce samych filmów.

Pierwotnie kanały książkowe koncentrowały się na recenzjach: czytelnicy streszczali treść i oceniali wybrane tytuły. Rozrastająca się wokół tych materiałów społeczność i szybki rozwój samego YouTube’a wymogły jednak stworzenie nowych, silniej i precyzyjniej stargetowanych form wypowiedzi, które umożliwiałyby pełne wykorzystanie potencjału videoblogów jako środka ekspresji i budowania więzi społecznych ${ }^{8}$. Doprowadziło to do wykształcenia się na

${ }^{5}$ Zob. A. Mara, K. Sorensen: BookTubers as a Networked Knowledge Community. W: Emerging Pedagogies in the Networked Knowledge Society. Practices Integrating Social Media and Globalization. Red. B. Gurung, M. Limbu. Hershey 2013, s. 92.

${ }^{6}$ Zob. J. Suchecka, N. Szostak: Nie przeszkadzaj, bo \#terazczytam. „Gazeta Wyborcza” 2016, nr 104, s. 13.

7 Zob. M.-Ch. Doulami: BookTube, czyli cyfrowe szaleństwo czytania. Tłum. P. Kasprzyk. http://www.cafebabel.pl/kultura/artykul/booktube-czyli-cyfrowe-szalenstwo-czytania.html [data dostępu: 10.01.2018].

${ }^{8}$ Zob. M. Majorek: Kod YouTube. Od kultury partycypacji do kultury uczestnictwa. Kraków 2015, s. 133. 
BookTubie konkretnych typów i konwencji nagrań, takich jak: bookshelf tour, book haul, readalong, bookathon (BookTube-A-Thon), wrap up oraz ich rozmaitych, wciąż uaktualnianych wersji ${ }^{9}$.

Pierwszy z nich, bookshelf tour (określany czasem przekornie jako bookshelfie), to nic innego jak wirtualna wycieczka po domowej biblioteczce autora filmu. W podobnych materiałach vlogerzy pokazują widzom posiadane książki — zdarza się, że prezentują je tom po tomie, przez co bookshelf tours są przeważnie najdłuższymi formami i trwają nawet do kilkudziesięciu minut. Vlogerzy zmniejszają w ten sposób dystans, jaki dzieli ich od publiczności, ponieważ pokazują fragmenty swoich prywatnych przestrzeni, których nie da się zastąpić przygotowaną naprędce scenografią czy wypożyczonym rekwizytem. Bookshelf tour stanowi więc ze strony booktuberów realne zaproszenie do strefy zarezerwowanej dla bliskich i znajomych. Jest to też oczywiście okazja do pochwalenia się własnym księgozbiorem, często imponującym, jak np. u Daniela i Natalii Muniowskich ze Strefy Czytacza, mających w swojej kolekcji wydania Harry'ego Pottera we wszystkich językach, w jakich ukazała się ta seria ${ }^{10}$.

Mając na uwadze obecność tak zaangażowanych booktuberów, nietrudno zrozumieć fenomen materiałów tytułowanych hasłem book haul, czyli książkowych zdobyczy. Vlogerzy aktualizują za ich pomocą informacje dotyczące swoich biblioteczek, opowiadając o tytułach, które je wzbogaciły oraz o źródłach, z których je pozyskali. Book haul pozwala więc nie tylko na przegląd nowości wydawniczych, ale również na zapoznanie się z możliwościami, jakie daje prowadzenie własnego bloga lub vloga i współpraca z wydawnictwami, na przypomnienie o istnieniu bibliotek czy refleksję na temat korzyści płynących z nawyku pożyczania książek od rówieśników.

Nieco inny charakter mają wszelkiego rodzaju akcje typu bookathon (pierwotnie BookTube-A-Thon) czy readalong, czyli maratony czytelnicze i inicjatywy opierające się na wyzwaniach. Ich nadrzędnym celem jest promowanie czytelnictwa, choć ważnym aspektem pozostaje również kwestia budowania wspólnoty. Uczestnicy mają możliwość zjednoczenia się we wspólnej (mimo że osobnej) lekturze — mogą na bieżąco dzielić się doświadczeniami, komentować i wymieniać uwagi, z czego zresztą chętnie korzystają. Niewątpliwie wpływa to korzystnie na motywację do przeczytania wybranego tekstu, nawet jeśli wydaje się on nieodpowiedni czy niedopasowany do gustu czytającego.

Przeczytane książki powracają natomiast w filmach oznaczanych jako wrap up — ich tradycja wywodzi się z tradycyjnych blogów książkowych, na których umieszczanie podsumowań miesiąca, roku czy maratonu czytelniczego właści-

9 Zob. K. Techavanich: BookTube - YouTube's Bookish Community. http://publiclibrarie sonline.org/2015/09/booktube-youtubes-bookish-community/ [data dostępu: 20.01.2018].

${ }_{10}$ Zob. D. Muniowski, N. Muniowska: (S)twórcy o sobie i o stronie. http://www.strefaczy tacza.pl/p/o-nas_27.html [data dostępu: 10.01.2018]. 
wie należy do standardu. Dla booktuberów wrap up to przede wszystkim okazja do wspomnienia o tytułach przeczytanych, ale nisko ocenionych lub po prostu mniej interesujących, a przez to niezrecenzowanych przez vlogera w postaci odrębnego formatu. Tym, co odróżnia wrap up od chociażby book haul, są właśnie elementy oceny zawarte w krótkich komentarzach opisujących wymieniane książki. To też jedna z niewielu konwencji, gdzie w sposób naturalny pojawiają się porównania oraz próby kategoryzowania zebranych tekstów.

Nie sposób nie wspomnieć również o Grze o BookTube, czyli propozycji rodzimego środowiska booktuberów. Inicjatorką i główną organizatorką przedsięwzięcia jest Maja K., która na potrzeby tego pomysłu stworzyła odrębny program, zapraszając do współpracy kilkoro innych vlogerów. W ramach Gry proponowała autorom kanałów książkowych udział w zabawach literackich — ich motywem przewodnim zawsze pozostawała literatura nurtu young adult, a więc popularna literatura młodzieżowa. Wyzwania sprawdzały u uczestników Gry znajomość treści książek, ale też autorów, tytułów, chronologii wydań i innych dopasowanych tematycznie szczegółów.

W centrum wszystkich wymienionych rodzajów booktube'owej publicystyki pozostaje oczywiście książka, rozumiana nie tylko jako określona treść zamknięta w fabule i stylu, ale również jako fizyczny obiekt, mogący stać się przedmiotem oglądu, pożądania lub niechęci, zabawy lub transakcji. W sposób najbardziej wyrazisty pokazuje to unboxing, polegający na nagrywaniu procesu rozpakowywania paczki z książkami (stąd propozycja polskojęzycznych booktuberów, by posługiwać się określeniem rozpaczking). Tradycja ta zrodziła się wraz z pomysłem wydawnictwa Moondrive na boxy, czyli pakiety zawierające wybraną książkę nurtu young adult oraz związane z nią tematycznie gadżety niespodzianki. W rzeczywistości BookTube'a książka przede wszystkim sprzedaje wrażenia i budzi emocje — a to przekłada się również na charakter vlogów.

\section{O książkach (nie) mówi się źle}

Mimo że wszelkie okołoksiążkowe materiały cieszą się niezwykłą popularnością, należy pamiętać, że tym, co definiowało BookTube’a u jego początków, była recenzja. Gatunek ten, w swojej tradycyjnej wersji, ma raczej niezmienny schemat, na który składają się takie elementy, jak: opis zjawiska, jego analiza krytyczna oraz ocena. W zależności od tego, która z wymienionych części dominuje, wyróżnić można recenzję informacyjną lub recenzję oceniającą ${ }^{11}$.

${ }^{11}$ Zob. E. Kozłowska: Recenzja jako forma podwójnego dialogu. W: Praktyczna stylistyka nie tylko dla polonistów. Red. E. Bańkowska, A. Mikołajczuk. Warszawa 2003, s. 288. 
Wskazuje się również na subiektywny charakter gatunku, przy jednoczesnym uwzględnieniu wiedzy i kompetencji samego recenzenta — ponieważ z założenia występuje on w roli eksperta i przewodnika ${ }^{12}$. Recenzja wydaje się ponadto gatunkiem łatwo przekładalnym na formę audiowizualną. Vlogerzy książkowi zaskakują jednak swoim podejściem do tematu, a to, jak rozumieją oni recenzję i co uznają za jej najważniejsze funkcje, wyznacza dwie główne drogi rozwojowe BookTube'a.

Pierwszą z nich jest wierność tradycji, czyli przygotowywanie materiału, którego treść skupia się na przekazie słownym, a środki filmowe są ograniczone do niezbędnego minimum. Recenzje te nagrywane są przeważnie na tle biblioteczek, ale nawet gdy zmienia się tło, to postać vlogera pozostaje stosunkowo statyczna i skupia na sobie całą uwagę odbiorcy. Na ogół w takich przypadkach recenzent zachowuje też równowagę pomiędzy poszczególnymi elementami składowymi wypowiedzi, a więc przytacza krótkie streszczenie fabuły, dodając krytyczne komentarze i analizując wybrane fragmenty, by w zakończeniu podsumować całość swoją oceną. Autorzy, którzy decydują się na takie rozwiązania, to głównie dorośli vlogerzy. Mają oni większe doświadczenia, często aktywnie działają w mediach oficjalnych lub mają kierunkowe wykształcenie. Wśród przykładowych kanałów wymienić należałoby przede wszystkim $T u$ czytam (prowadzony przez absolwentki polonistyki), Krótka przerwę Justyny Sucheckiej i Natalii Szostak oraz Czytam, bo muszę Elżbiety Zdanowskiej (dwa ostatnie tworzone przez publicystki $)^{13}$.

$\mathrm{Na}$ drugim biegunie znajdują się recenzje młodego pokolenia, wśród których dominuje dbałość o formę i atrakcyjność wizualną przygotowywanych materiałów. Do grupy tej należy zaliczyć m.in. Maję K., Wybredną Marudę, BookReviews by Anita i Strefę Czytacza, ale również kanały prowadzone przez młodzież szkolną. Booktuberzy ci są wyjątkowo kreatywni i nie obawiają się eksperymentów z montażem (dzięki któremu niektóre recenzje przypominają profesjonalne zwiastuny książkowe) czy z charakteryzacją, odwołującą się do kultury fandomu i tradycji cosplayerów, bliskich fanom młodzieżowej literatury popularnej. Różnice widoczne są również w treści recenzji. Ich funkcja informacyjna jest ograniczona, jako że wzmianki na temat fabuły są lakoniczne, co wynikać może z wyraźnie widocznej tendencji do obawiania się spoilerów i unikania ich. Młodzi booktuberzy zdecydowanie koncentrują się więc na elemencie oceniającym, akcentując wyraźnie subiektywizm wydawanych sądów. Znamienna jest także silna emocjonalność ich wypowiedzi, wpływająca zresztą na płynność wystąpień - słowa zastępowane są przez mimikę, gesty,

12 Zob. ibidem, s. 289.

${ }_{13}$ Zob. E. Zdanow ska: Idealny kanat na YouTube, czyli co oglądam przed zaśnięciem. http:// czytambomusze.pl/idealny-kanal-na-booktubie-czyli-co-ogladam-przed-zasnieciem/ [data dostępu: 10.01.2018]. 
a nawet nieartykułowane dźwięki (westchnięcia, piski, łkanie) czy wymowne milczenie.

Zarówno dla jednej, jak i drugiej grupy booktuberów charakterystyczne są jednak ograniczenie tytułów pojawiających się na kanałach oraz stosunkowo niewielka ilość ocen negatywnych. Część vlogerów książkowych tłumaczy tę sytuację chęcią promowania jedynie dobrej literatury (zgodnie z zasadą, że rozgłos sprzyja popularyzacji, bez względu na to, czy jest to rozgłos pozytywny, czy negatywny), wciąż często zarzuca się im jednak zbyt silne uzależnienie od wydawnictw i patronów. Problem ten stanowić może ciekawy pretekst do rozmowy na temat funkcjonowania krytyki literackiej, a nawet na temat zasadności stosowania tego określenia w stosunku do amatorskich przecież nagrań młodych miłośników książek.

\section{Moda na czytanie}

Książka jest w modzie nie od dziś, i to w każdym znaczeniu tego słowa. Pisała o tym Krystyna Koziołek: zwracała uwagę na żurnalowe fotografie z sesji wykorzystującej książkę jako rekwizyt, snuła refleksję na temat sposobów czytania i osobności człowieka pogrążonego w lekturze. Zaproponowała przy tym ideę haute lecture, czyli lektury wysokiej, elitarnej, niespiesznej i refleksyjnej ${ }^{14}$. Booktube'owa moda na czytanie to koncept zgoła odmienny — promuje czytanie głośne, momentami wręcz hałaśliwe, nie zawsze wnikliwe. Jest to jednak głos młodego pokolenia, dotąd raczej niesłyszany lub skutecznie ignorowany, który wreszcie zdołał przebić się przez medialny szum i upomnieć się o swoje prawa. Co istotne, o jego skuteczności świadczy nie tylko liczba wyświetleń filmów, ale fakt, że sprowokował reakcję ze strony wydawnictw.

I tak oto wydawnictwo Moondrive zdecydowało się na zorganizowanie akcji crowdfundingowej, aby przetłumaczyć i wydać powieść Illuminae Amie Kaufman, nie rezygnując z jej oryginalnego opracowania edytorskiego. Czwarta Strona zaangażowała natomiast środowisko vlogerów książkowych do organizacji życia literackiego młodzieży — wspierania promocji nowych tytułów, prowadzenia spotkań autorskich i promowania nowych nazwisk na rynku (w tym młodych, polskich debiutantów podejmujących próby wypełnienia niszy, jaką stanowi rodzima literatura dla młodzieży), a nawet włączyła związaną z BookTubem społeczność w proces decydowania o tym, które z zagranicznych

${ }^{14}$ Zob. K. Koziołek: Haute lecture albo książka w modzie. „Świat i Słowo” 2011, nr 1, s. 219. 
bestsellerów doczekają się polskiej premiery (m.in. ustanowienie tytułów Ambasadorów Czwartej Strony [YA!]).

Być może warto więc nie skupiać się na słabościach BookTube’a, lecz zauważać jego osiągnięcia, spróbować zachęcić młodzież do wejścia w kulturę uczestnictwa - nie ograniczać się więc do śledzenia cudzych kanałów poświęconych książkom, ale stworzyć własny, który eliminowałby błędy poprzedników i doskonalił najlepsze, najciekawsze rozwiązania. Bo, cytując Czwartą Stronę: „We need YA”. Potrzebujemy młodych dorosłych ${ }^{15}$.

\section{Bibliografia}

Hys J.: Jak nie czytam, jak czytam. Bijemy rekord czytania w jednym momencie!. „Biblioteka w Szkole" 2017, nr 3.

Koziołek K.: Haute lecture albo ksiązka w modzie. „Świat i Słowo” 2011, nr 1.

Kozłowska E.: Recenzja jako forma podwójnego dialogu. W: Praktyczna stylistyka nie tylko dla polonistów. Red. E. Bańkowska, A. Mikołajczuk. Warszawa 2003.

Majorek M.: Kod YouTube. Od kultury partycypacji do kultury uczestnictwa. Kraków 2015.

Mara A., Sorensen K.: BookTubers as a Networked Knowledge Community. W: Emerging Pedagogies in the Networked Knowledge Society. Practices Integrating Social Media and Globalization. Red. B. Gurung, M. Limbu. Hershey 2013.

Suchecka J., Szostak N.: Nie przeszkadzaj, bo \#terazczytam. „Gazeta Wyborcza” 2016, nr 104.

Zasacka Z.: Czytelnictwo dzieci i młodzieży. Warszawa 2014.

\section{Źródła internetowe}

Doulami M.-Ch.: BookTube, czyli cyfrowe szaleństwo czytania. Tłum. P. Kasprzyk. http://www. cafebabel.pl/kultura/artykul/booktube-czyli-cyfrowe-szalenstwo-czytania.html.

Hetman R.: O tym, dlaczego jestem stary i co ogladam na BookTubie. https://czytamrecenzuje. pl/1034/o-tym-dlaczego-jestem-stary-i-co-ogladam-na-booktubie.

Muniowski D., Muniowska N.: (S)twórcy o sobie i o stronie. http://www.strefaczytacza.pl/p/o-nas_27.html.

Techavanich K.: BookTube - YouTube's Bookish Community. http://publiclibrariesonline.org/ 2015/09/booktube-youtubes-bookish-community/.

Zdanowska E.: Idealny kanat na YouTube, czyli co ogladam przed zaśnięciem. http://czytambomusze.pl/idealny-kanal-na-booktubie-czyli-co-ogladam-przed-zasnieciem/.

https://pl-pl.facebook.com/WeneedYAbooks/.

15 https://pl-pl.facebook.com/WeneedYAbooks/ [data dostępu: 30.01.2018]. 